\title{
Family law without lawyers - a systems theory perspective
}

Adrienne Barnett

Brunel Law School, Brunel University London, UK*

\begin{abstract}
Prior to the loss of legal aid for many litigants in private law Children Act proceedings occasioned by the Legal Aid, Sentencing and Punishment of Offenders Act 2012, family lawyers were observed to pressurise victims of domestic violence to agree to unsafe contact orders. Drawing on Luhmann's theory of autopoietic social systems, this article suggests that, since April 2013, family lawyers have been repositioned as the champions of victims of domestic violence, and considers what this tells us about the way in which family law is observed to operate without lawyers in many cases. It suggests that the problems that LIPs create for the orderly running of proceedings and the continued operations of the legal system have led to a perceived crisis for justice, but that family law is likely to survive without lawyers in many cases, although little change can be observed in the substantive law.
\end{abstract}

\section{Key words}

Child arrangements/contact; domestic violence; autopoietic systems theory; litigants in person; family lawyers

\section{Introduction}

On $18^{\text {th }}$ February 2016 the organisation Rights of Women won a landmark appeal against the government. ${ }^{1}$ The Court of Appeal held that the requirement that evidence verifying domestic violence for the receipt of legal aid for private law Children Act proceedings has to be dated within a two-year period before the application is made, and that the lack of provision for victims of financial abuse, stipulated in the regulations made under the Legal Aid, Sentencing and Punishment of Offenders Act 2012 ('LASPOA'), are invalid. This decision should assist

\footnotetext{
*CONTACT Adrienne Barnett Email: adrienne.barnett@brunel.ac.uk

${ }^{1}$ The Queen (On the Application of Rights of Women) $v$ The Lord Chancellor and Secretary of State for Justice [2016] EWCA Civ 91
} 
many victims of domestic violence who, since April 2013 when LASPOA came into effect, have not been able to obtain legal aid for representation in such proceedings because they could not provide the requisite evidence. However, it is suggested that the decision also presents an opportunity for us to consider how family lawyers represent victims of domestic violence when negotiating agreements for child arrangements (formerly residence and contact). ${ }^{2}$

There is no doubt that many victims of domestic violence up and down the country benefit enormously from, and consider invaluable, the advice, support and representation they receive from the dedicated solicitors and barristers who specialise in family law in England and Wales, including their efforts to reach negotiated agreements to avoid contested litigation. ${ }^{3}$ Concerns have been expressed, however, where such 'agreement' arises out of intentional or unintentional coercion, and/or endangers victims' safety This article considers how it is that family lawyers, who prior to LASPOA were observed as complicit in securing enforced and/or unsafe agreements for child arrangements/contact, have now been repositioned as the champions of victims of domestic violence, and what this tells us about the way in which family law is observed to operate, and is likely to operate, without the assistance of lawyers in many cases. In so doing, this article draws on Niklas Luhmann's theory of autopoietic social systems, which has powerful explanatory potential for exploring the problems and possibilities not only for parties to legal proceedings but for the legal system itself and its continued operations, when it may no longer rely on the participation of lawyers.

\section{Luhmann's theory of autopoietic social systems}

The theory of autopoietic social systems was developed by the German sociologist, Niklas Luhmann, who was interested in 'how social order was possible if the contrary, chaos, was so much more plausible' (Ziegert, 2005, p. 51; see also Messner, 2014). Where Luhmann differs from other contemporary social theorists is in seeing the phenomenal world (the world that has meaning for us) constructed at two distinct levels - the psychic and the social - and it is

\footnotetext{
2 The term 'child arrangements' replaced 'residence' and 'contact'. The term, 'child arrangements/contact' will be used in this article in order to cover the pre- and post-2014 position.

${ }^{3}$ See, eg, Eekelaar, Maclean \& Beinart (2000); Maclean \& Eekelaar (2016); Trinder, Hunter, Hitchings, Miles, Moorhead, Smith, Sefton, Hinchley, Bader \& Pearce (2014)
} 
the interaction between them which, at the level of individual consciousness, enables individuals to make sense of the external world (see King, 1997, p. 189; Teubner, 1993). For systems theorists, modern society's identity, its conception of itself, is the product of the operations of its normatively closed, differentiated systems, which provide the authority and justification for social communications (King, 1997).

Systems are produced and reproduced entirely by their operations, and in the case of social systems, these operations are communications. Rather than consisting of people, for systems theorists society is the totality of all meaningful communications (see King, 2009, p. 52; Luhmann, 2004, p. 189; Luhmann, 2013,p. 219). Over time western societies have evolved from stratified and hierarchical differentiation, to functionally differentiated subsystems such as law, politics, economics and science, with no ultimate hierarchical authority (King, 1997, p. 131; Thornhill, 2006, p. 76). None of society's subsystems can replace the knowledge-creating and interpretive functions of other systems or is able to offer an exclusively 'correct' view of society: only law may decide what is lawful; politics what is national policy; science what is scientifically true or false (King 1997; Priban 1997). Law's function in modern society is to maintain normative expectations in the face of disappointment (Luhmann, 1989; 2004). Unlike cognitive expectations, which enable us to learn from experience and disappointment, normative expectations are sustained in the face of communications that report on contrary facts' (Nobles \& Schiff, 2013, p. 136).

In order to distinguish itself from its environment (which includes other systems), each system operates a binary scheme based on its own unique code that structures its communications and produces the boundaries of the system (Luhmann, 2004, p. 182). Law codes events in its environment using the form legal/illegal, and produces communications based on this distinction (Luhmann, 2004; Priban, 1997). It is this continuous coding that enables the system to generate itself by the network of its own operations (communications), thereby perfecting its own autopoiesis. ${ }^{4}$ Luhmann defines an autopoietic social system as one that 'produces and reproduces its own elements by the interaction of its elements' (Luhmann, 1989, p. 136; see also Luhmann, 2013, p. 77). Only law enables us to determine in advance whether particular conduct would be answerable to law, and whether it will be legal or illegal

\footnotetext{
${ }^{4}$ The term, 'autopoiesis', derives from the biological term formulated by the scientists Humberto Maturana and Francisco Varela, for an organism that reproduces itself from its own elements.
} 
(Luhmann, 2004, p. 193). Even legal validity is determined by law itself as there is 'no value test for validity outside the system itself' (Nobles and Schiff, 2004, p. 13).

However, the process of coding alone cannot determine how the code values (legal or illegal) are to be assigned, that is, it is an opposition with no content or a distinction with no meaning in itself (Luhmann, 2004, p. 192; Nobles \& Schiff, 2004, p. 45). So asking whether the distinction between legal and illegal itself is legal or illegal leads to a paradox that could be a contradiction (legal is illegal) or a tautology (legal is what is legal). It is through the system's programmes (legislation, case law, rules of procedure and evidence) that the positive or negative code values are assigned to facts in the system's environment.

It is important to note that different communications can be made in the same institutional setting. So not everything that judges communicate are legal communications just because they are judges, and individuals may make legal communications anywhere and at any time. As discussed below, judges and lawyers frequently communicate in the system of 'child welfare science' (child health, psychology and psychiatry) (King \& Piper, 1995), while Cafcass officers and mediators often communicate in the legal system. The point is that the legal system is invoked by the use of its code.

Autopoetic systems are operationally and normatively closed to the external world by the process of self-referential coding. This means that social systems cannot communicate directly with each other in the same way that individuals cannot communicate directly with, or steer, a social system. 'Information from outside the legal system, for example, cannot enter the system as raw data... Instead [it has] to be coded by the system - that is, given meaning within the system's programmes.' (King, 1997, p. 166; Van Krieken, 2006). Although society's subsystems cannot communicate directly or interpenetrate, they are, however, cognitively open. This means that they are capable of being irritated by their observations of the environment and in this way are able to learn and remain responsive to the 'external' world. ${ }^{5}$ In particular, social systems are dependent on other social systems producing authoritative communications on which they are able to rely.

\footnotetext{
${ }^{5}$ An irritation is an event that occurs in one or more social systems, which causes that system to respond by reconstituting it in ways that the system can understand (see King, 1997; Luhman, 2013).
} 
The concept of 'observation' plays a central role in the selective production of meaning by social and conscious systems. For Luhmann, observation means the drawing of distinctions which indicate one side and not the other (see Luhmann, 2013). By introducing the observer (one to whom we attribute a statement), Luhmann escapes the subject/object distinction and relativises ontology.

' $[\mathrm{O}]$ ntology is no longer the assumption of a reality that is shared, and of which it can be assumed that everyone sees the same facts... Instead, ontology becomes itself a schema of observation...on the basis of difference. ... One always faces the question of who says a particular thing, and who does something, and from which system perspective the world is seen in a particular way (and no other).' (Luhmann, 2013, p. 99)

A communication system is an observer and the observations are carried out by means of the system's operations, i.e., communications (Luhmann, 2013, p. 105). In this way, the world becomes contingent because everything that is observed depends on the selected distinction and indication, and, at the level of second-order observation, on how that observation, in turn, is observed (Christis, 2001; Luhmann, 2013, p. 112). Because observation is a selective operation, it involves a reduction in complexity. Systems cannot, however, observe their own selectivity, so 'reality for that system becomes whatever is accessible, that is whatever it selects and recognizes as real' (King, 2009, p. 71). This does not mean that the world 'out there' does not exist and is simply an invention of social or psychic systems; rather, that the meanings by which we understand the world are structured through social and psychic systems' internal constructs of the external world (Luhmann 2013, p. 86; Patterson \& Teubner, 2005, p. 235).

The basic distinction for systems theory is between system and environment, a difference that is produced by the recursive, autopoietic operations of the system itself (Ashenden, 2006; Luhmann, 2013, p. 63). So the environment evoked by each system is not the 'real world' out there but its own internal version of reality generated by its internal processes (Ashenden, 2006, p. 131; Luhmann, 2004, pp. $73 \& 83$ ). Society forms part of the environment of people (conscious systems), just as people are not 'in' the social system but are part of its environment. 
If people wish to participate in society, they need to operate socially, that is, communicate, which occurs when consciousness is 'structurally coupled' with communications, because it is impossible to imagine communication if there is no consciousness and vice versa (Luhmann, 2004, p. 416). ${ }^{6}$ Language provides the structural mechanism through which this coupling is stabilised (King, 2009, pp. 59-61; Luhmann, 2013; Seidl, 2004). Shared meanings produce tighter structural coupling, for example, between communications of the legal system and the consciousness of those familiar with its meanings such as judges and lawyers. This has important implications for the ability of the legal system to continue operating when litigants are not represented by lawyers.

By directing the lens of autopoietic systems theory on the transformed world of family law, we can see that at the root of the way in which that world is currently observed, is the problem of compulsory decision-making, that is, the obligation of judges to decide every case submitted to them for a decision.

\section{The problem of compulsory decision-making}

Under modern conditions, courts, 'the organised decision-making system of the legal system', occupy the centre of the system, and other structures such as lawyers, clients and the legislature, form the periphery (Luhmann, 2004, p. 158). Courts have the unique role of decision-making, while the periphery 'is not subject to compulsory operation' (Luhmann, 2004, p. 294). The problem, for law, is its self-description as a decision-maker, that is, "when a system promises to give an answer to every question and forces all the operations of the system to presuppose that there is such an answer' (Luhmann, 2004, p. 429, emphasis in original; see also Nobles \& Schiff, 2014). One way in which law manages decision-making is by translating the decision into further distinctions, which may be based on the concept of reasons. With repeated and generalised use, reasons develop into principles, which legitimate their own re-use while simultaneously excluding other reasons (see further Luhmann, 2004, pp. 328-331). Procedural programmes (such as the burden and standard of proof, rules of evidence) also provide courts with distinctions to assist decision-making.

\footnotetext{
6 'Structural coupling' is Luhmann's term for the situation where systems' operations form stable patterns for each other (Luhmann, 2004, 82).
} 
Compulsory decision-making, however, poses risks for the system, as it means that the decision may be 'branded as the causal factor [of harm] and expose it to the effect of retrospective regret' (Luhmann, 2004, p. 155). This risk is excluded by the typical form of the legal system's conditional programmes - 'if X occurs then $\mathrm{Y}$ is legal'- which prevents 'any future facts, not accounted for at the time of the decision, from being relevant to a decision concerning legal and illegal' (Luhmann, 2004, P. 198). Purpose-specific programmes like those of politics (which are judged on their results), on the other hand, cause problems for the legal system, as they lay the decision open to the risk of being assessed on its future consequences. The increasing promulgation of purpose-specific legislation in areas such as family law creates problems for law's function of generating normative expectations (Luhmann, 2004, p. 202; Nobles \& Schiff, 2013, p. 13).

\section{'The welfare of the child' and 'domestic violence'}

The problem for private law Children Act cases is that its primary legislative programmes are entirely purpose-specific - the requirement in Section 1 of the Children Act 1989 that the welfare of the child is the court's paramount consideration when making Section 8 orders, and the welfare checklist in S 1(3), provide no conditions for determining how the selection between legal and illegal is to be made in any particular case (Nobles \& Schiff, 2013, p. 140). Law has resolved this problem by introducing a conditional programme that attributes a positive value to the contact side of the distinction, 'contact/no contact'. This has been achieved by law selecting information from child welfare science (which society has vested with the sole authority to determine children's best interests) and portraying this as arising out of a consensus within the scientific literature, namely, that continued contact between children and their biological parents is 'good' for children's emotional, psychological and developmental health (Barnett, 2009, 2014a \& b; King, 1997; King \& Piper, 1995, 1996).

The result of this selective construction is that, within the world constituted by law, the impression can be given that it is able to advance children's welfare by applying this scientific 'truth', despite the contingent, complex, ambiguous and contradictory body of clinical, research and theoretical literature within child welfare science that reveals no firm conclusions on how children's welfare on parental separation can best be served (see further Barnett, 2014a \& b). However, the legal 'truth' about children's welfare on parental separation has developed sufficient redundancy (meaning that stays the same) with repeat use to develop into a principle or 'presumption'. This means that there is no need for law to make 
further reference to external authorities, thereby illustrating the autopoietic nature of the legal system (Newnham, 2011, 3; Nobles \& Schiff, 2014).

Law still has to be able to respond legally to cases of illegality, i.e., where contact between a child and non-resident parent is denied by the resident parent. This has been achieved by law creating exceptions (a further conditional programme) structured around the distinction 'cogent/trivial' reasons to deny contact:

\begin{abstract}
"No court should deprive a child of access to either parent unless it was wholly satisfied that it was in the interests of the child that access should cease, and that was a conclusion at which the court should be extremely slow to arrive. ... the test to be applied was whether there were cogent reasons why the child should be denied the opportunity of access to their natural father." (Re D (A Minor (Contact: Mother's Hostility) [1993] 2 FLR 1, per Balcombe LJ at pp. 3-4. $)^{7}$
\end{abstract}

Until the late 1990s, in the environment constructed by child law, domestic violence was rarely selected as a 'cogent reason' to deny contact (see, e.g., Re M (A Minor) (Contact: Conditions) [1994] 1 FLR 272; Re F (Minors) (Contact: Mother's Anxiety) [1993] 2 FLR 830; Re O (Contact: Imposition of Conditions) [1995] 2 FLR 124). However, responding to irritations from feminist campaigning and research, from the late 1990s and particularly since the Court of Appeal decision in Re L, V, M, H (Contact: Domestic Violence) [2000] 2 FLR 334 , domestic violence has been attributed by law as potentially being a cogent reason to deny or restrict contact. ${ }^{8}$ Whether or not domestic violence is observed as a 'cogent reason' in a particular case depends on a further distinction that has been developed, namely, whether or not the violence is 'relevant' to contact. Family lawyers play an important role in operationalising 'relevance' and in constructing law's environment in child arrangements/contact cases by the way in which they advise and represent victims of domestic violence.

\title{
The role of family lawyers
}

\footnotetext{
${ }^{7}$ This formula has been affirmed in numerous subsequent cases such as Re H (Contact) (Principles) [1994] 2 FLR 969; Re O (Contact: Withdrawal of Application) [2003] EWHC 3031 (Fam), [2004] 1 FLR 274

${ }^{8}$ See also Re M (Contact: Violent Parent) [1999] 2 FLR 321; Re M (Interim Contact: Domestic Violence) [2000] 2 FLR 377
} 
Despite the generation of principles and presumptions, decision-making in private family law cases continues to carry risks for law's social function of maintaining normative expectations, and is onerous, practically and intellectually, for judges. Family lawyers have a crucial role to play in constructing an environment amenable to decision-making by courts, by selectively excluding arguments, claims or 'facts' that clients may wish to put to the court, and constructing 'narratives from the chaos of events and acts' (Eekelaar et al, 2000, p. 80; see also Nobles \& Schiff, 2004, p. 33).

However, courts only decide a very small number of cases that enter the environment of private family law, ${ }^{9}$ largely because of the role played by family lawyers in negotiating settlements. This shifts the risks of decision-making from courts by attributing decisions to the parties themselves. Numerous studies have revealed the efforts made by solicitors and barristers to negotiate agreements for child contact and residence, and the success they have in achieving this (Davis, Cretney \& Collins, 1994; Eekelaar et al., 2000; Maclean \& Eekelaar, 2016). Lawyers utilise a range of approaches and strategies to encourage clients to reach agreement on contact, including both legal and non-legal forms of communication (King, 1999, p. 102), for example, referring to what they consider the court would be likely to order and the 'needs' of the children for contact. ${ }^{10}$

'So it's about trying to push on them that it's in the child's best interests to have contact with dad or mum...You know, it is important to maintain the relationship with the parent... because I always say to parents: neither of you are going to get what you want, you're going to have to compromise or the court will enforce something upon you that neither of you are going to like, nine times out of ten' (Ms D, Solicitor, SE, in Barnett, 2014a, p. 188).

According to family lawyers' own observations, these strategies can be very successful: 'Usually I ask them directly because normally we have instructions and then you go through what the court expects and often you can turn them round in ten or fifteen minutes. That they will lose, on the facts' (Ms F, Barrister, SE, in Barnett, 2014a, p. 188).

\footnotetext{
${ }^{9}$ Bailey-Harris, Barron \& Pearce (1999); Eekelaar et al. (2000); Eekelaar \& Maclean (2010); Harding \& Newnham (2015); Maclean \& Eekelaar (2009, 2016); Neale \& Smart (1999); Piper (1999)

${ }^{10}$ Bailey-Harris, Davis, Barron \& Pearce (1998); Coy, Perks, Scott \& Tweedale (2012); Dewar \& Parker (1999); Eekelaar et al. (2000); Hunter \& Barnett (2013); King (1999); Piper (2000); Piper \& Day Sclater (1999); Smart (1995).
} 
However, some family lawyers themselves have observed their own practices as putting pressure on mothers to compromise: 'I mean, I think they sometimes feel to a degree that they have been coerced into agreeing because there's been a fair degree of pressure from either the court or Cafcass or even their own legal advisers' (Ms T, Barrister, NW, in Barnett, 2014b, p. 446).

Coerced agreements may be observed as particularly problematic where domestic violence is a feature of the case.

\title{
Domestic violence and child arrangements - advice or coercion?
}

\begin{abstract}
'Many relationships have domestic violence in them but only a fraction of contact cases fail... When you look at how bloody awful some of our cases are and the experiences of the children, it's remarkable how few cases no contact is ordered. It is remarkable given we deal with the toughest ten per cent of cases where relationships break down and there are children.' (Mr J, FCA, NE, in Barnett, 2014a, p. 294)
\end{abstract}

To what extent is this situation attributable to the practices of family lawyers? Substantial research evidence over many years has consistently found domestic violence to be an issue in approximately 50 per cent of private law Children Act cases. ${ }^{11}$ This prevalence, and the small number of cases in which orders for contact are decided rather than agreed, means that a large proportion of cases involving allegations of domestic violence are settled by agreement for contact rather than adjudicated on. Harding and Newnham (2015) found that contested final hearings are rare even in cases where allegations of domestic violence are made. ${ }^{12}$

Research undertaken prior to the implementation of Practice Direction 12J (discussed further below) revealed the extent to which family lawyers pressurise women to agree to unsafe contact arrangements rather than be viewed as 'hostile' or 'unreasonable' by courts. ${ }^{13}$

\footnotetext{
${ }^{11}$ Buchanan, Hunt, Bretherton \& Bream (2001); Cassidy \& Davey (2011); Harding \& Newnham (2015); Hunt \& Macleod (2008); Hunt, Macleod \& Thomas (1999); Perry \& Rainey (2007)

${ }^{12}$ For similar findings see Coy et al. (2012); Hunt and Macleod (2008); Hunter \& Barnett (2013)

${ }^{13}$ Barnett (2000); Buchanan et al. (2001); Hester \& Radford (1996); Humphreys \& Harrison (2003); Kaganas \& Piper (1999); Neale \& Smart (1997, 1999); Perry \& Rainey (2007); Radford, Sayer \& AMICA (1999); Women's Aid (1997)
} 
Professionals tended to see domestic violence as an obstacle to be overcome on the way to agreeing contact, rather than 'in terms of client's safety or freedom from intimidation' (Kaganas \& Piper, 1999, p. 195; see also Anderson 1997). Solicitors themselves told Hunt and Macleod (2008) that they participated in the pressure on clients to reach agreement. If encouragement and persuasion of mothers failed to achieve the desired outcome of agreement for contact, a harsher, more coercive approach was adopted, including threats of change of residence.

\section{Practice Direction 12J and beyond}

Such was the concern about coerced contact agreements that in 2006 Lord Justice Wall requested the Family Justice Council ('FJC') to consider the extent to which unsafe consent orders were being negotiated by professionals and sanctioned by the courts in contact and residence proceedings as a consequence of pressure being put on victims of domestic violence to agree to contact (Wall LJ 2006). The subsequent report produced by the FJC found that the assumption that contact is in a child's best interests and that it will inevitably be ordered by the court 'sometimes results in pressure being put on victims of domestic violence by lawyers, or by perpetrators of that domestic violence, to agree to an order' (Craig, 2007, p. 28). As a result, unsafe contact agreements were often made because of the advice given to parents. The FJC recommended that a Practice Direction should be issued embodying the $\operatorname{Re} L$ guidelines and the recommendations of the FJC. Accordingly, Practice Direction 12J ('PD12J') was issued by the President of the Family Division in May 2008. ${ }^{14}$

Research undertaken since PD12J was implemented strongly suggests that family lawyers have not significantly changed their practices. Additionally, although 'domestic violence' may be attributed with a broader meaning than it was in the past (Barnett, 2014a \& b), only allegations of recent, very serious physical violence are observed by judges and family lawyers to be relevant to child arrangements/contact (Coy et al., 2012; Thiara and Gill, 2012; Hunter and Barnett, 2013; Barnett, 2014a \& b; Harding and Newnham, 2015). Domestic violence that is seen as historic or not serious enough is disregarded (Hunter and

\footnotetext{
${ }^{14}$ Potter P, Practice Direction: Residence and Contact Orders: Domestic Violence and Harm [2008] 2 FLR 103, reissued as amended at [2009] 2 FLR 1400; subsequently incorporated in the Family Procedure Rules 2010 as PD12J.
} 
Barnett, 2013). ${ }^{15}$ This example of an 'unnecessary' fact-finding hearing gives an indication of the kind of circumstances in which family lawyers might encourage clients to agree to contact:

\begin{abstract}
"It was mid-level violence... punching, kicking, pushing her over, smashing the flat, that sort of thing...nothing where she really needed much help from the hospital other than painkillers. No stabbings, or anything nasty, again I hate to minimise.” (Ms E, Barrister, London, in
\end{abstract} Barnett, 2014a, 236)

Family lawyers may use the same strategies as they employ in cases where domestic violence has not been raised as an issue, such as persuading mothers to be 'sensible' and 'reasonable', or 'explaining why some things that they think may be extremely pertinent, or relevant, aren't' (Ms S, Barrister, NW, in Barnett, 2014a, p. 187).

The pressure that may be put on victims of domestic violence to agree to contact has been observed by some family lawyers as extremely concerning:

'In one case I had a mini-pupil with me and I said: I have a view about where this case should go, have a view about this father and how controlling he is, but I also have to be careful as her professional adviser not to take the father's place in that relationship because I didn't want her to feel that I was putting pressure on her not, you know, to appease me...I think it can be quite abusive, the relationship that we sort of have with our clients ...If my client's not ready to come up to there then it's my job to protect her and make sure that she is not pushed into anything and shoving her about.

Interviewer: Do all family lawyers share this view?

No, and they're quite bombastic and actually all they're doing is taking the place of the perpetrator and they put pressure on them.' (Ms P, Barrister, SW, in Barnett, 2014a, p. 191)

However, like most other family lawyers interviewed by Barnett, even Ms P indicated that she would persuade the mother to agree to interim contact when presented with a hypothetical case scenario involving disputed allegations of domestic violence:

${ }^{15}$ PD12J enjoins courts to consider, when domestic violence is raised as an issue, 'the extent to which it would be likely to be relevant in deciding whether to make a child arrangements order and, if so, in what terms' (Para. 6). 
'As I said to my lady this morning, that at the final hearing you want them to be the sort of picture of reasonableness so, you know, it's a fine balance for your client, about making sure if they want contact to take place...then knowing that the court will want contact to take place and it will take a dim view of contact not taking place.' (Ms P, Barrister, SW, in Barnett, 2014a, p. 273)

Most family lawyers interviewed by Barnett indicated that even if domestic violence is proved, they would advise the mother to agree to direct contact, and it is only in very extreme circumstances that they would support her in opposing this.

'I would tell her to get real, and start thinking positively, not for her sake but for the child's sake because, from experience, this can backfire in later life and the child could turn on her and it has happened... and it is always a problem, that if this continues, this situation continues, then residence may be in question.' (Ms F, Barrister, SE, in Barnett, 2014a, p. 291).

It is not suggested that pressure on victims of domestic violence to agree to child arrangements/contact may only emanate from family lawyers. Cafcass officers (Coy et al., 2012), non-resident parents and their representatives (Barnett, 2014a), and the courts also have an important role to play in this respect. Some Cafcass officers interviewed by Barnett observed family lawyers and courts together colluding to reach agreement without the involvement of the FCA:

'I've run into court in the end because they were just about, they said: it's been agreed. I said: there's issues of horrendous domestic violence here that haven't been looked at and I'm recommending full welfare reports... [The mother's] view was that she wanted a quiet life, she didn't want to make it difficult because if she makes things difficult he then becomes abusive...It drives me mad really. They must have known I wouldn't agree to it...[but] they did listen.' (Ms N, FCA, SW, in Barnett, 2014a, p. 200)

Since contested fact-finding and final hearings are very uncommon, it would seem that family lawyers are largely successful in their efforts to persuade clients to agree to contact, since there is substantial evidence attesting to the fact that orders refusing direct contact are 
extremely rare. ${ }^{16}$ In 2011 , less than 0.3 per cent of contact applications were refused (Ministry of Justice, 2012).

The point is not that family lawyers put more pressure on their clients to agree to contact than do courts, Cafcass officers or non-resident parents' representatives (although in some cases this may well be the case). Rather, as Davis observed: 'Where the parties are at their most vulnerable - in conflict with one another and confronted with legal machinery which they do not understand - the only "support" worth having may be that which is unashamedly partisan' (1998, pp. 89-90). However, in the process of persuading clients who oppose child arrangements/contact on the basis of domestic violence to agree, family lawyers are contributing to the constitution of an environment that reinforces legal constructions of children's welfare and the 'relevance' of domestic violence to child arrangements/contact.

\section{Post-LASPOA: Family lawyers - the victims' champions}

Since LASPOA was implemented, the numbers of litigants in person ('LIPs') in private law Children Act cases has increased substantially. Nearly one third of cases in the period April to June 2015 involved neither party being represented (compared to 10\% in January to March $2011),{ }^{17}$ which has provoked considerable alarm in legal and extra-legal circles.

What is striking, however, is that despite the pressure that may be put on victims of domestic violence by their own representatives to agree to unsafe child arrangements/contact, almost overnight since the enactment of LASPOA and subsequently, family lawyers have been reconstructed as their champions. This in no way does a disservice to those family lawyers who support and 'stand up for' their clients; the point is that all family lawyers are now seen by legal and moral observers as beneficial for victims of domestic violence.

What is even more striking is the concern expressed that, without representation by lawyers, victims of domestic violence may be coerced into agreeing to unsafe contact arrangements. 'Pressure to reach speedy resolution may mean that women accede to arrangements which are not necessarily in their own or their children's best interests.' (Coy et

\footnotetext{
${ }^{16}$ Barnett (2014a); Cassidy \& Davey (2011); Coy et al. (2012); Harding \& Newnham (2015); Hunt \& Macleod (2008); Hunter \& Barnett (2013); Thiara \& Gill (2012)

${ }^{17}$ Ministry of Justice (2015)
} 
al., 2012, p. 40; see also Hunter \& Barnett, 2013; Trinder et al., 2014; written evidence from various respondents to the Commons Select Committee's inquiry into LASPOA ['CSC'], 2014) As discussed above, this may well be the case, but this concern ignores the role that family lawyers themselves may play in pressurising clients into agreeing to contact.

However, what appears to overshadow the apprehension expressed about victims of domestic violence being coerced into agreements for contact, is the inability of LIPs to negotiate agreements, and the impact of LIPs generally on the operations of the legal system. These concerns may be responsible for the swift repositioning of family lawyers as the solution, rather than a cause, of some of the problems for victims of domestic violence. The way in which LIPs operate in the legal system has the potential not only to increase the numbers of contested hearings but also to render decision-making a great deal more difficult. As a consequence, an increased focus on procedural issues at the expense of substantive norms and outcomes can be detected, and on the problems observed to be caused for the system by LIPs rather than the difficulties experienced by LIPs, although the latter are certainly not ignored. This appears to have fuelled a perceived 'crisis' for justice and the validity of law in this area. The discussion that follows explores the main areas of concern the inability of LIPs to negotiate agreements for contact; the inability of LIPs to understand the law or the 'correct' issues, or indeed to communicate at all; and the difficulties LIPs have managing the court and trial process.

\section{Inability/refusal of LIPs to negotiate agreement}

' $\mathrm{J}]$ udges recognise that one of the great problems about both parties representing themselves in proceedings is that far too often there is no constructive dialogue between the parties outside of the court hearings which makes constructive negotiations, settlement and marrying issues to be virtually impossible and therefore only a final hearing determines many cases' (Emmerson \& Platt, 2014, p. 520).

There is substantial evidence suggesting that cases involving LIPs are less likely to settle because LIPs are unable to communicate directly with the other party due to high levels of animosity, distrust and/or fear, and when facing a represented opponent they refuse to engage in discussions out of court with their lawyer (Moorhead \& Sefton, 2005; Maclean \& 
Eekelaar, 2009; Judiciary of England \& Wales, 2013; Hitchings, Miles \& Woodward, 2013; Trinder et al., 2014; CSC, 2014).

This anxiety about the inability or refusal of LIPs to negotiate agreements for child arrangements/contact appears to eclipse the concerns voiced about victims of domestic violence being coerced into unsafe contact agreements, and it is notable that domestic violence is entirely absent from these communications. By attributing a positive value to settlement, LIPs in law's environment who are unable or unwilling to negotiate agreements are therefore inept, unreasonable or obstructive. Family lawyers play an important part in the reduction of the complexity of law's environment and the constitution of an environment amenable both to agreement-seeking and decision-making. This can be seen in the pervasive concern that LIPs are unable to communicate or introduce the 'wrong issues'.

\section{LIPs do not understand the law and introduce the 'wrong issues'}

As discussed above, successful communication can only occur if consciousness is structurally coupled with communication. If individuals wish to participate in a social system they need to become 'familiar with the language, various processes, procedures, roles of the social institutions that administer the operations of the function systems' (King, 2009, p. 113). In order to participate in the legal system (as in any other social system) people have to 'learn to recognise redundancy, and to utilise it in the construction of their communications. And, on the negative side, there is a cost to any human actor who fails to identify redundancies, which is to fail successfully to make the communication, and to achieve the operation that they would have wished to achieve' (Nobles and Schiff, 2013, p. 33). Unrepresented parties to legal proceedings have to construct their communications using the same redundancies as judges, otherwise 'judges would not have the ability to make successful communications' (Nobles and Schiff, 2013, 37). The problem for many LIPs and therefore for the legal system is that they do not understand legal concepts (redundancies). However, they also do not formulate their interests correctly. Interests have to be 'prepared and presented for the legal system and its operations in such a way that they make reasoned decisions possible particularly where there is conflict' (Luhmann, 2004, 347). The problem for the system, therefore, is that the inability of LIPs to recognise redundancies or formulate legally justified interests may inhibit system communication. 
'[LIPs do not know how to produce] meaningful statements focussed on the relevant issues or how to differentiate between appropriate and hopelessly immaterial lines of inquiry... Rather the tendency can be for the LIP to concentrate upon factors with no or only incidental relevance to the outcome.' (Judicial Executive Board, 2014)

'They'll tell you everything in case it might be relevant and you don't want to shut them up in case they might come on to a relevant point. But you've got to, eventually. And it's very difficult to be able to get them to be focused on what's relevant. They just don't know what's going to be relevant.' (Participant in Court A Judicial focus group in Trinder et al., 2014; see also Trinder, 2014, p. 666)

There are not, of course, objectively 'wrong' and 'right', or 'relevant' and 'irrelevant' issues and factors when it comes to children's welfare - the world 'out there' does not categorise itself. These distinctions and selections and the causal relations they construct are 'a contingent enterprise, an observer-dependent ascription or attribution that could have been different' (Luhmann, as cited in Borch, 2005, p. 157).

Some of these 'incorrect' or 'irrelevant' factors could be reasons expressed by resident parents for seeking to deny or restrict contact:

'Although it seems perfectly rational to the parent themselves, actually from the court's point of view, and from Cafcass's point of view, and from the non-resident parent's point of view and from the child's point of view also at least, it's completely irrational what's being done.' (Mr J, FCA, NE in Barnett 2014a , p. 166)

However, external observers of the system may see the 'irrelevant' issues and reasons as highly pertinent. A number of social science researchers have observed a very different environment from the one constituted by law, seeing disputes over contact as involving very serious issues such as child sexual abuse, violence, child abduction and poor parenting (Maclean \& Eekelaar, 2009; Buchanan et al., 2001; Trinder et al., 2014).

The ability of LIPs to participate in the legal system varies substantially, from a small minority with competence to advocate on their own behalf, to vulnerable LIPs at 'the vanquished end' of the spectrum who are literally unable to communicate (Trinder et al., 2014 , p. 26). There can be no doubt, therefore, that representation by lawyers can confer a 
huge benefit not only on those LIPs who struggle to communicate in the system, but also on the system itself and its ability to continue operating.

\section{Concern about LIPs managing proceedings}

'The court system is based on an adversarial, full representation model with two lawyers presenting their client's cases to an impartial arbiter - the judge - who will make a decision. The role of lawyers is central. Hearings where both parties were represented were generally patterned, predictable and efficient. All participants understood their roles without any need for explanation or behaviour management. LIP hearings were far less standardised. There was considerable variation in who picked up the tasks that a lawyer would normally perform in their absence - whether it was a LIP, the judge, the lawyer for the represented party or nobody. There was also variation in how effectively those tasks were done.' (Trinder et al., 2014, p. 77)

One of the greatest concerns expressed by numerous commentators is the inability of LIPs to manage the technicalities and procedural aspects of their cases, which could propel vulnerable LIPs 'towards the vanquished end of the capacity spectrum' (Trinder et al., 2014, p. 28). These include obtaining and preparing documentation such as application forms, statements and schedules; preparing bundles; and obtaining evidence (including expert evidence, police disclosure and hospital records) (Moorhead \& Sefton, 2005; Coy et al., 2012; Hunter \& Barnett, 2013; Williams, 2011; CSC, 2014; Harding \& Newnham, 2015).

This has led to great consternation about the problems that LIPs are creating for the orderly running of proceedings. A major complaint is that proceedings are slower and cases take longer and are more difficult to manage where LIPs are involved, resulting in the entire court system suffering from delays. ${ }^{18}$

Law's environment, therefore, is populated by litigants who prevent law operating efficiently and are problems in themselves, rather than people with problems to be solved.

\footnotetext{
${ }^{18}$ Cobb (2014, p. 665); Eekelaar et al. (2000, p. 109); Harding \& Newnham (2015); Hunter \& Barnett (2013); Judicial Executive Board (2014, p. 4); Moorhead \& Sefton (2005); Trinder et al. (2014).
} 
'Generally, I encounter difficulties every day in the courts I attend with litigants in person not knowing how to go about things, not being willing to negotiate, not understanding the issues or being able to 'narrow them down' and generally demanding their day in court. The Judges are worn to shreds dealing with them, as are we!' (Family Law Bar Association (FLBA), a member's account, 2014)

Not only are LIPs observed to be causing problems for the orderly running of proceedings; they may also be seen to threaten law's ability to dispense justice, or 'due process'. In $\operatorname{Re} C$ (Due Process) [2013] EWCA Civ 1412 both parties were unrepresented. The mother's application form and statement, in which she indicated that the father had been violent and threatening towards her, were characterised as incorrectly and inconsistently drafted, which was observed by the Court of Appeal as a threat to the father's right to a fair trial: '[T]his father was denied natural justice at almost every stage of the proceedings. Lack of competent legal representation played its part.' (per Macur LJ, at para. 54) So, rather than the mother being seen as a vulnerable and disadvantaged LIP in need of support, she was observed as endangering the father's right to a fair trial.

\section{Legal representation as 'justice'}

This discussion may lead us to question whether the 'legality' of decision-making is now observed as more problematic than the substance of the decisions. Law's binary code applies to legal decisions themselves, so that the court's decisions have to comply with law's own internal test of legality.

\footnotetext{
'Proceedings ....allow the distinction between legal and illegal to be applied to the proceedings themselves. A special procedural law, which is carefully distinguished from substantive law, is created for the regulation of proceedings. ... Procedural injustice is therefore a violation of procedural norms.' (Luhmann, 2004, p. 207, emphasis in original)
}

There has been pervasive concern about the potential injustice that may arise from the difficulties LIPs can experience giving oral evidence and cross-examining witnesses (Coy et al., 2012; Trinder et al., 2014; CSC, 2014). A barrister gave an example of a case in the written evidence of the FLBA to the Commons Select Committee's inquiry into LASPOA where he acted for the father in a fact-finding hearing against an unrepresented mother who 
'was completely unable to effectively cross-examine the father... the outcome I am sure [was] more favourable to my client than had she been represented' (FLBA, 2014, p. 9).

However, nowhere is the concern about legality and justice more evident than on the issue of victims of domestic violence being cross-examined by unrepresented perpetrators (Coy et al., 2012; Trinder et al., 2014; CSC, 2014). It is clear that victims of domestic violence do find this enormously difficult and distressing (Rights of Women, Women's Aid \& Welsh Women's Aid, 2014). This issue, however, seems to have been reconstructed, in the case law, into a concern for the rights of the perpetrator to have representation in order to cross-examine the victim. In a series of High Court cases, the availability of counsel to represent the alleged perpetrators of sexual offences that included rape and child abuse, has come to be observed as a fundamental requirement of justice for the perpetrator. In $Q v Q$ (Funding of Representation and Expert Attendance) [2014] EWFC 7 Sir James Munby held that lack of representation potentially breached the requirements that courts should ensure that cases are 'dealt with expeditiously and fairly' and 'that the parties are on an equal footing' (Rule 1.1 of the FPR 2010), as well as the father's rights under Article 6 of the European Convention on Human Rights ('ECHR'). Sir James Munby invited the Ministry of Justice to make submissions about the father's funding being met by the mother's legal aid certificate or directly at the court's expense, an invitation that the Ministry of Justice declined.

In $Q v Q ; \operatorname{Re} B ; \operatorname{Re} C$ (Private Law: Public Funding) [2014] EWFC 31, Sir James Munby stated that questioning of the alleged victim by the judge on behalf of the father could breach the father's Articles 6 and 8 ECHR rights because the judge would not hear adversarial argument and the father would be deprived of legal advice. He therefore held that the judge could direct the court service to fund the alleged perpetrator's representation. HHJ Bellamy in Re K and H (Children: Unrepresented Father: Cross-Examination of Child) [2015] EWFC 1 had also directed the court service to bear the costs of the father's representation. However, these attempts to secure government funding for the representation of alleged perpetrators were eventually rejected by the Court of Appeal in $\operatorname{Re} K$ and $H$ (Children) [2015] EWCA Civ 543 on the basis that the judge had no power to make the order. However, as discussed below, the Court of Appeal resolved the 'due process' issue by distinguishing between 'complex' and straightforward cases, in which lack of representation would be unlawful in the former case but lawful in the latter. 
Lack of legal representation was, therefore, observed by law in these cases as giving rise to a crisis of justice, namely, the possibility of legal decision-making being illegal because of breaches of procedural norms of justice, with no way of treating that illegality legally. We can see, therefore, why, for law, process is more important than outcome because procedure observed as illegal could stop law operating in such proceedings. What appears to underlie this crisis of justice is the changing role of the judge.

\section{The judge's role}

Legal observers see enormous problems for the obligatory decision-making role of judges where parties are not represented.

\footnotetext{
'The judicial members of the FJC...all report a sea change in their work since the introduction of LASPO. Judges are of the view that their role as an independent arbiter is being undermined as they struggle to assist parties who have little or no understanding of the legal issues involved in their cases, the process and procedures of litigation and unrealistic expectations as to outcomes.' (FJC, 2014, p. 4)
}

A number of legal and extra-legal commentators have observed the judge's role as becoming more 'inquisitorial' (see, e.g., FJC, 2014, p. 5). The problem is that the questioning of a party by the judge on behalf of the other party can be observed as both 'legal' and 'illegal', and there is nothing inherent in the distinction itself to guide the judge. So, for example, HHJ Bellamy in $\operatorname{Re} K$ and $H$ noted that questioning of parties and witnesses by the judge in cases involving LIPs already happens regularly and is not 'inherently incompatible with the protection of Art 6 and Art 8 European Convention rights' (at para. 43). ${ }^{19}$ It is also observed to be legal by Paragraph 28 of PD12J which requires judges to consider conducting 'the questioning on behalf of the other party...in order to ensure both parties are able to give their best evidence'. On the other hand, in $D$ and $K$ and B (A child, by her guardian) [2014] EWHC 700 (Fam), HHJ Wildblood observed such questioning to be illegal, doubting whether a judge or the child's solicitor could question the mother about allegations of rape on behalf of the father in the same way that a lawyer representing the father could, which would not meet the justice of the father's case.

\footnotetext{
${ }^{19}$ See also Re C (Due Process) [2013] EWCA Civ 1412 per Ryder $U$ at para. 48
} 
HHJ Bellamy in Re $K$ and $H$ unfolded the paradox (of legal/illegal questioning by the judge) by distinguishing between legal questioning (in straightforward cases) and illegal questioning, 'when the case involves issues which are grave and/or forensically complex', a distinction that was approved by the Master of the Rolls when the case went on appeal. The Master of the Rolls invited Parliament to consider enacting legislation to enable payment from central funds to be available for 'the appointment of a legal representative to conduct the cross-examination' in cases where the evidence is complex and expert, or complex and confused. Needless to say, to date Parliament has not done so.

But even 'legal' questioning of a witness by a judge carries the risk of illegality. The Master of the Rolls in $\operatorname{Re} K$ and $H$ commented that if questioning by a judge of a witness is not 'conducted sensitively and fairly... then this of itself may give rise to a breach of article 6 and 8'(at para. 59). It is little wonder that judges may observe their role, in the absence of lawyers, to be so problematic, when there is always the risk that their communications may be observed to be unjust or unlawful.

Not only are judges expected effectively to act for parties; they also have to undertake dispute resolution to replace the lawyer's settlement-seeking function, a role that is a legal expectation under the Child Arrangements Programme ('CAP'). However, whereas lawyers can anticipate a decision without it losing the status of a decision, it becomes more difficult for judges to indicate to parties that they should agree because of what the judge will decide, and then continue to operate, if no agreement is concluded, on the basis that the decision has not yet been reached.

\section{Family law without lawyers - the future}

The question is how family law will develop or even survive without lawyers available to advise and represent litigants in many cases. The biggest threat to the future of private family law, it is suggested, may be posed not directly by LIPs but by the withdrawal of conflicts from law, or even the rejection of the legal code by law and other social systems. Luhmann explains that 'law learns from conflicts. Without conflicts law would not develop, would not be reproduced, and would then be forgotten' (Luhmann, 2004, p. 477). However, despite a fall in the numbers of private law Children Act applications issued after LASPOA was implemented (Ministry of Justice, 2014, 13), more recently the numbers have subsequently 
risen, and were 13 per cent higher in April to June 2015 than in the equivalent period in 2014 (Ministry of Justice, 2015).

On the other hand, law and other sub-systems such as politics could reject law altogether in the area of post-separation disputes between parents about children, which means rejection of the 'legal/illegal' code (Luhmann, 2004, p. 179). However, the only 'true rejection of law is a refusal to code' but this actually involves 'the application of the code of another system in place of coding through law' (Nobles and Schiff, 2004, p. 21). This could involve judges undertaking the tasks hitherto performed by the periphery of the system. 'Judges cannot just assume a role of "engaged neutrality" in the new era: they have to be investigators, conciliators, advisers, case managers, and of course a vital referral agent' (Cobb, 2014, p. 646). In performing some of these tasks, however, 'judges would no longer be operating in the legal system' (Luhmann, 2004, p. 201).

Instead, law may be rejected in favour of other systems such as mediation. The legal aid changes were accompanied by a renewed drive by politics and law to promote mediation, which attributes parents with the decision-making role, thus absolving courts from being the risk-takers in cases of children's futures (King, 1997, p. 203). Law's promotion of mediation, for example through the CAP, provides law with the legal means of renouncing its authority to regulate arrangements for children after parental separation and divorce. But does this mean that 'the possibility of having the case decided under the legal code is [no longer] guaranteed' (Luhmann, 2004, p. 196)?

It is suggested that, on the contrary, rather than mediation replacing law, we could observe law expanding into mediation, with legal communications progressively operating in the context of 'mediation', particularly since increasing numbers of solicitors are training as mediators. The difficulty for mediation is that it is not yet an autopoietic, functional subsystem of the social system. Its code - 'agreement/no agreement' - is not unique to mediation, and mediators' 'skill set is drawn from many disciplinary skills ranging from financial and legal to the social and psychological' (Maclean \& Eekelaar, 2016, 73). Additionally, the various codes of practice differ on the issue of giving legal advice, some encouraging mediators to inform parties whether their proposals are legally acceptable, others discouraging this form of communication (see further Maclean \& Eekelaar, 2016). So, rather than mediation replacing law, we may see law expanding its operations into mediation. In any 
event, the expected rise in mediation did not happen and the conversion rate from Mediation Information and Assessment Meetings ('MIAMs') to mediation is low (Maclean \& Eekelaar 2016; Family Law Week 31 March 2016).

\section{A reduction in the complexity and consistency of law?}

'[T]he heightened familiarity of some actors with systems' communications (tighter structural coupling between individual psychic systems and social systems) is in turn a precondition for the increased complexity of social systems.' (Nobles and Schiff, 2013, p. 251)

The difficulties many LIPs have understanding the law, and the reduced number of lawyers available to develop legal arguments and ensure that judges themselves apply the law legally, could result in a reduction in both the complexity and consistency of private family law. However, any such concern presupposes that prior to the increase in LIPs, family law was applied consistently, and lawyers developed its complexity. This is not necessarily the case. For example, monitoring of the Re L guidelines by the Lord Chancellor's Department found that their application was inconsistent and 'patchy' and that the guidelines were frequently ignored (DCA \& DfES, 2004). Subsequently, courts and family lawyers sometimes ignored PD12J (see, eg, Re W (Children: Domestic Violence) [2012] EWCA Civ 1619; Re H (Interim Contact: Domestic Violence Allegations) [2013] EWCA Civ 72).

The amended PD12J which came into effect in April 2014 is a lengthy and complex text comprising legal and non-legal communications, which could have the potential to increase the variety (new information) and complexity of private family law if it is correctly applied and not ignored. However, as will now be discussed, existing redundancies in this area of law are remarkably stable and resilient.

\section{For victims of domestic violence - business as usual?}

Since LASPOA came into effect, there have been far fewer reported private law Children Act cases than prior to its implementation. A large proportion of those that have been reported have focused on the 'due process' issues discussed above. However, in virtually all of the reported cases, no change can be detected in communications regarding the substantive law. In every one of their judgments, the appellate judges have emphasised the importance of continued contact between children and non-resident parents (the father in all cases but one): 
'Contact between parent and child is a fundamental element of family life and is almost always in the interests of the child. ... Contact between parent and child is to be terminated only in exceptional circumstances, where there are cogent reasons for doing so and when there is no alternative. Contact is to be terminated only if it will be detrimental to the child's welfare' (per Ward LJ in Re C (A Child) (Suspension of Contact) [2011] EWCA Civ 521 at para. 47 ; this formulation was adopted by the post-LASPOA case law). ${ }^{20}$

Applying this formula, the Court of Appeal overturned a number of decisions by trial judges who refused direct contact between children and violent fathers, on the basis that the judge 'has a duty to promote such contact and to grapple with all available alternatives before abandoning hope of achieving some contact. Contact should be stopped only as a last resort and once it has become clear that the child will not benefit from continuing the attempt' (Re $R$ (No Order for Contact Appeal) [2014] EWCA Civ 1664 per Christopher Clarke LJ at para. 16; see also Re M (Children) [2013] EWCA Civ 1147 per Macur LJ).

It is notable that none of the reported cases base their decisions on (or even refer to) the presumption of parental involvement in Section 2A of the Children Act 1989, which provides that the court is 'to presume, unless the contrary is shown, that involvement of that parent in the life of the child concerned will further the child's welfare...in a way that does not put the child at risk of suffering harm'. ${ }^{21}$ This means that the statutory provision has thus far failed to generate variety in the system, possibly because the presumption is considerably less forceful than the 'best interests' formulations produced by the case law.

Even where trial judges have refused to order direct contact because of findings of domestic violence against the father, most appeals against these decisions have been successful. For example, in Re M (A child) 25 November 2015 (unreported but referred to in Re K (Children) [2016] EWCA Civ 99), findings of physical and verbal violence, which the

\footnotetext{
${ }^{20}$ See also Re M (Parental Responsibility) [2013] EWCA Civ 969; Re J-M (A Child)[2014] EWCA Civ 434; Re V (A Child) (Inadequate Reasons for Findings of Fact) [2015] EWCA Civ 274; Re Q (A Child) [2015] EWCA Civ 991; Re T (A Child: Suspension of Contact: Section 91(14) CA 1989) [2015] EWCA Civ 719; Re F (Children) [2015] EWCA Civ 1315.

${ }^{21}$ Section 2A of the Children Act 1989 was introduced by Section 11 of the Children and Families Act 2014, and is included in summary form in Paragraph 4 of PD12J.
} 
child had witnessed, were made against the father, who refused to attend a Domestic Violence Perpetrator Programme ('DVPP'); accordingly, the judge had refused to order direct contact. Macur LJ allowed the father's appeal on the basis that the judge should have ignored or at least challenged the Cafcass officer's recommendation for the father to attend a DVPP. In Re K (Children) [2016] EWCA Civ 99 the Court of Appeal rejected the father's lack of responsibility and remorse for his violent, controlling and aggressive behaviour towards the mother as a reason to deny him contact.

Alternatively, the appellate courts may continue to exclude domestic violence from law's environment on the basis that it is not 'relevant' to contact. In $\operatorname{Re} V$ (A Child) (Inadequate Reasons for Findings of Fact) [2015] EWCA Civ 274, McFarlane LJ castigated Cafcass officers 'and other professionals' for assuming that 'in any case where the label "domestic abuse" or "domestic violence" is used ... all such allegations need to be thoroughly investigated no matter how old or disconnected to the child they may be and, more worryingly, that all such allegations, if found proved, indicate that there should be no direct contact between the abusive parent' (at para. 34).

\section{Conclusions}

LIPs have been observed to generate enormous problems for the continued operations of the legal system, by introducing the 'wrong' interests, failing to identify and understand legal rules and concepts, and being unable or unwilling to settle cases, or being, quite literally, unable to communicate at all. Judges are increasingly having to undertake the role of lawyers and to spend time dealing with issues that normally would have been dealt with earlier or not at all (Trinder et al., 2014).

Observing lack of representation for alleged perpetrators as 'unjust' or 'illegal' could have led to parts of the family law system grinding to a halt. We have seen, however, that legal communication is a remarkably resilient operation. The Court of Appeal decision in $R e$ $K$ and $H$ ensured that the system could continue to operate legally. Nevertheless, in cases involving LIPs, law's self-description as a decision-maker still invests an almost impossible task in judges, who have to walk a communicative tightrope without knowing whether their decisions will be observed in the future as fair or just by external observers and, more importantly, as legal or illegal, by law. 
It is no wonder, then, that family lawyers are now observed as so important for litigants but more particularly, for the legal system. By selecting out and excluding much of what clients communicate to them, family lawyers enable judges not only to decide cases with far less difficulty, but to avoid decision-making in child arrangements/contact cases altogether by brokering child arrangements orders.

The perceived crisis caused by LASPOA and the great concern for victims of domestic violence that it generated could have been an opportunity for the legal system to 're-think' its operations in private family law. Instead, nothing appears to have changed in the substantive law for victims of domestic violence. Furthermore, the impossibility of systems being able to directly 'steer' each other to achieve 'progress' is demonstrated by the way in which the concern of moral observers for victims of domestic violence being cross-examined by their abusers found legal form in the protection of the due process rights of alleged perpetrators.

It is also debatable whether those victims of domestic violence who may still be represented by family lawyers in private law Children Act proceedings will experience any change. In fully represented cases, those lawyers may be put under even greater pressure by the beleaguered judiciary to negotiate agreements for child arrangements/contact. On the other hand, without lawyers to erase the unappealing aspects of perpetrators, and with an increased role for Cafcass officers, we may see rather different outcomes in the lower courts where victims of domestic violence oppose direct contact, as the few reported cases indicate.

It is almost inevitable that law will be 'judged' from very different viewpoints from its own internal image of itself. Whether a court's decisions are considered 'fair' or 'just' depends on how they are observed, and in particular, 'upon the particular moral view taken by different observers' (King, 1997, 45). So, whether current developments in private family law are 'good' or 'bad' for the children and parents who live in the world 'out there' will depend on how the future is observed. For law, however, as Luhmann's theory shows us, 'there is no future beyond the self-referential selections made as communications within society and its various functioning sub-systems. The future is out there, but for society it can only be grasped through communications' (Nobles \& Schiff, 2004, p. 52).

[10,470 words excluding Abstract and key words] 


\section{References}

Anderson, L. (1997). Contact between Children and Violent Fathers. London: Rights of Women.

Ashenden, S. (2006). The Problem of Power in Luhmann's Systems Theory. In M. King \& C. Thornhill (Eds.), Luhmann on Law and Politics (pp. 127-144). Portland, Oregon: Hart Publishing.

Bailey-Harris, R., Davis, G., Barron, J., \& Pearce J. (1998). Monitoring Private Law Applications under the Children Act 1989. Report to the Nuffield Foundation. Bristol: University of Bristol.

Bailey-Harris, R., Barron, J., \& Pearce, J. (1999). Settlement Culture and the use of the "no order' principle under the Children Act 1989. Child and Family Law Quarterly, 11, 53-62.

Barnett, A. (2000). Contact and Domestic Violence: The Ideological Divide. In J. Bridgeman \& D. Monk (Eds.), Feminist Perspectives on Family Law (pp. 129-150). London: Cavendish.

Barnett, A. (2009). The Welfare of the Child Re-Visited: In Whose Best Interests? Part 1. Family Law, 39, 50-54.

Barnett, A. (2014). Contact at all costs? Domestic violence, child contact and the practices of the family courts and professionals. (Doctoral thesis). Brunel University, London, http://bura.brunel.ac.uk/bitstream/2438/8753/1/FulltextThesis.pdf

Borch, C. (2005). Systemic Power: Luhmann, Foucault and analytics of Power. Acta Sociologica, 48(2), 155-167.

Buchanan, A., Hunt, J., Bretherton, H. \& Bream, V. (2001). Families in Conflict: Perspectives of children and parents on the Family Court Welfare Service. Bristol: The Policy Press.

Cassidy, D. \& Davey, S. (2011). Family justice and children's proceedings: a review of public and private law case files. Research Summary 51/1. London: Ministry of Justice. Retrieved from https://www.gov.uk/government/uploads/system/uploads/attachment_data/file/217368/family -justice-childrens-proceedings.pdf

Christis, J. (2001). Luhmann's theory of knowledge: beyond realism and constructivism? Soziale Systeme, 7, 328-349.

Cobb, S. (2014). Private Law Reform. Family Law, 44, 664-668. 
Commons Select Committee. (2014). Impact of changes to civil legal aid under the Legal Aid, Sentencing and Punishment of Offenders Act 2012. (Written Evidence of Respondents). Retrieved from http://www.parliament.uk/business/committees/committees-a-z/commonsselect/justice-committee/inquiries/parliament-2010/laspo/?type=Written

Coy, M., Perks, K., Scott, E., \& Tweedale, R. (2012). Picking up the pieces: Domestic violence and child contact. London: Rights of Women. Retrieved from http://rightsofwomen.org.uk/wp-content/uploads/2014/10/Picking_Up the Pieces_Report20121.pdf

Craig, J. (2007). Everybody's Business: Applications for Contact Orders by Consent. Family Law. 37, 26-30.

Davis, G. (1998). Partisans and Mediators. Oxford: Oxford University Press.

Davis, G., Cretney, S., \& Collins, J. G. (1994) Simple Quarrels: Negotiating Money and Property Disputes on Divorce. Oxford: Clarendon Press.

Department of Constitutional Affairs \& Department for Education \& Skills. (2004). The Government's Response to the Children Act Sub-Committee ('CASC') Report: 'Making Contact Work'. London: DCA \& DfES.

Dewar, J. \& Parker, S. (1999). The Impact of the New Part VII Family Law Act 1975. Australian Journal of Family Law, 13, 96-116.

Eekelaar, J., Maclean M., \& Beinart, S. (2000). Family Lawyers: The Divorce Work of Solicitors. Oxford \& Portland, Oregon: Hart Publishing.

Eekelaar, J. \& Maclean, M. (2013). Family Justice: The work of family judges in uncertain times. Oxford: Hart Publishing.

Emmerson, D. \& Platt, J. (2014). Legal Aid, Sentencing and Punishment of Offenders Act 2012: LASPO Reviewed. Family Law, 44, 515-523.

Family Justice Council. (2014). Written Evidence from the Family Justice Council (LAS 82) the operation of the Legal Aid Sentencing and Punishment of Offenders Act 2012. Retrieved from

http://data.parliament.uk/writtenevidence/committeeevidence.svc/evidencedocument/justicecommittee/impact-of-changes-to-civil-legal-aid-under-laspo/written/9268.pdf

Family Law Bar Association. (2014). Written Evidence from the Family Law Bar Association (LAS 69). Retrieved from

http://data.parliament.uk/writtenevidence/committeeevidence.svc/evidencedocument/justicecommittee/impact-of-changes-to-civil-legal-aid-under-laspo/written/8973.pdf 
Family Law Week. (31 March 2016). Retrieved from

http://www.familylawweek.co.uk/site.aspx?i=ed160031

Harding, M. \& Newnham, A. (2015). How do County Courts Share the Care of children Between Parents? Full Report. Coventry: University of Warwick. Retrieved from http://www.nuffieldfoundation.org/sites/default/files/files/Full\%20report.pdf

Hester, M. \& Radford, R. (1996). Domestic Violence and Child Contact Arrangements in England and Denmark. Bristol: The Policy Press.

Hitchings, E., Miles, J. \& Woodward, H. (2013). Assembling the jigsaw puzzle: understanding financial settlement on divorce. Bristol: University of Bristol. Retrieved from http://www.bristol.ac.uk/law/research/researchpublications/2013/assemblingthejigsawpuzzle. pdf

Humphreys, C. \& Harrison, C. (2003). Squaring the Circle - Contact and Domestic Violence. Family Law, 33, 419-423.

Hunt, J. \& Macleod, A. (2008). Outcomes of applications to court for contact orders after parental separation or divorce. London: Ministry of Justice. Retrieved from http://dera.ioe.ac.uk/9145/1/outcomes-applications-contact-orders.pdf

Hunt, J., Macleod, A., \& Thomas, C. (1999). The Last Resort: Child Protection, the Courts and the 1989 Children Act. London: TSO.

Hunter, R. \& Barnett, A. (2013). Fact-Finding Hearings and the Implementation of the President's Practice Direction: Residence and Contact Orders: Domestic Violence and Harm. London: Family Justice Council 2013. Retrieved from https://kar.kent.ac.uk/35678/1/FFH\%20report\%20January\%202013.pdf

Judicial Executive Board. (2014). Written Evidence of the Judicial Executive Board. Retrieved from http://data.parliament.uk/writtenevidence/committeeevidence.svc/evidencedocument/justicecommittee/impact-of-changes-to-civil-legal-aid-under-laspo/written/9472.pdf

Judiciary of England and Wales. (2013). Judicial Working Group on Litigants in Person: Report. London: Judiciary of England and Wales. Retrieved from https://www.judiciary.gov.uk/wp-content/uploads/JCO/Documents/Reports/lip_2013.pdf

Kaganas, F. \& Piper, C. (1999). Divorce and Domestic Violence. In S. Day Sclater \& C. Piper (Eds.), Undercurrents of Divorce. Aldershot: Ashgate.

King, M. (1997). A Better World for Children. London: Routledge. 
King, M. (1999). 'Being sensible': Images and Practices of the new Family Lawyers. 28 Journal of Social Policy, 28, 249-273.

King, M. (2009). Systems, not People, make Society Happen. London: Holcombe Publishing. King, M. \& Piper, C. (1995). How the Law Thinks about Children. Aldershot: Ashgate.

King, M. \& Piper, C. (1996). Divorce Reform and the Image of the Child. Journal of Law and Society, 23, 364-382.

Law Society, CILEX, The General Council of the Bar. (2015). Litigants in person: guidelines for laywers. London: The Law Society, CILEX, \& The General Council of the Bar. Retrieved from http://www.lawsociety.org.uk/support-services/advice/articles/litigants-in-person-newguidelines-for-lawyers-june-2015/

Luhmann, N. (1989). Law as a Social System. Northwestern University Law Review, 83, 136150 .

Luhmann, N. (2004). Law as a Social System. Oxford: Oxford University Press.

Luhmann, N. (2013). Introduction to Systems Theory. Cambridge: Polity Press.

Maclean, M. \& Eekelaar, J. (2009). Family Law Advocacy: How Barristers Help the Victims of Family Failure. Oxford: Hart Publishing.

Maclean, M. \& Eekelaar, J. (2016). Lawyers and Mediators. Oxford: Hart Publishing.

Messner, C. (2014). Luhmann’s Judgment. Int. J. Semiot. Law, 27, 359-387.

Ministry of Justice. (2012). Judicial and Court Statistics 2011. London: Ministry of Justice. Retrieved from https://www.gov.uk/government/uploads/system/uploads/attachment_data/file/217494/judicia 1-court-stats-2011.pdf

Ministry of Justice. (2014). Court Statistics Quarterly April-June 2014. Retrieved from https://www.gov.uk/government/uploads/system/uploads/attachment data/file/358230/courtstatistics-quarterly-april-to-june-2014.pdf

Ministry of Justice. (2015). Family Court Statistics Quarterly April to June 2015. Retrieved from

https://www.gov.uk/government/uploads/system/uploads/attachment_data/file/462910/family -court-statistics.pdf

Moorhead, R. \& Sefton, M. (2005). Litigants in person. London: Ministry of Justice. 
Neale, B. \& Smart, C. (1997). 'Good' and 'bad' lawyers: Struggling in the shadow of the new law, Journal of Social Welfare and Family Law, 19, 377-402.

Neale, B. \& Smart, C. (1999). In Whose Best Interests? Theorising Family Life Following Parental Separation or Divorce. In S. Day Sclater \& C. Piper (Eds.), Undercurrents of Divorce. (pp. 33-54). Aldershot: Ashgate.

Newnham, A. (2011). The use of shared residence arrangements in English and Swedish family law: in the child's best interests or a covert resurrection of traditional patriarchal structures? (Doctoral thesis), University of Sussex, Brighton. Retrieved from http://sro.sussex.ac.uk/6331/1/Newnham\%2C_Annika_Brandberg.pdf

Nobles, R. \& Schiff, D. (2004). Introduction. In N. Luhmann. Law as a Social System. (pp. 152). Oxford: Oxford University Press.

Nobles, R. \& Schiff, D. (2013). Observing Law Through Systems Theory. Oxford: Hart Publishing.

Nobles, R. \& Schiff, D. (2014). Luhmann: Law Justice and Time. Int. J.Semiot. Law, 27, 325340 .

Patterson, J. \& Teubner, G. (2005). Changing Maps: Empirical Legal Autopoiesis. In R. Banakar \& M. Travers, (Eds.). Theory and Method in Socio-Legal Research (pp. 215-238). Oxford: Hart Publishing.

Perry, A. \& Rainey, B. (2007). Supervised, Supported and Indirect Contact Orders: Research Findings. International Journal of Law, Policy and the Family, 21, 21-47.

Piper, C. (1999). How do you define a family lawyer? Legal Studies, 19, 92-111.

Piper, C. (2000). Assumptions about children's best interests. Journal of Social Welfare and Family Law, 22, 261-276.

Piper, C. \& Day Sclater, S. (1999). Changing Divorce. In S. Day Sclater \& C. Piper (Eds.), Undercurrents of Divorce. Aldershot: Ashgate.

Potter, P. (2008). Practice Direction: Residence and Contact Orders: Domestic Violence and Harm [2008] 2 FLR 103, reissued as amended at [2009] 2 FLR 1400.

Priban, J. (1997). Beyond procedural legitimation: legality and its 'infictions'. Journal of Law and Society, 24, 331-347. 
Radford, L., Sayer, S., \& AMICA. (1999). Unreasonable Fears? Child Contact in the Context of Domestic Violence: A Survey of Mother's Perceptions of Harm Bristol: Women's Aid Federation.

Rights of Women, Women's Aid \& Welsh Women's Aid. (2014). Evidencing domestic violence: a year on. Retrieved from http://rightsofwomen.org.uk/wpcontent/uploads/2014/10/Evidencing-DV-a-year-on-2014.pdf

Seidl, D. (2004). Luhmann's Theory of autopoietic social systems. Munich: LudwigMaximilians-Universitat-Munchen. Retrieved from http://www.zfog.bwl.unimuenchen.de/files/mitarbeiter/paper2004_2.pdf

Smart, C. (1995). Losing the Struggle for Another Voice: The Case of Family Law. Dalhousie Law Journal, 18, 173-195.

Teubner, G. (1993). Law as an Autopoietic System. Oxford: Blackwell.

Thiara. R. \& Gill, A. (2012). Domestic Violence, Child Contact, Post-Separation Violence: Experiences of South Asian and African-Caribbean Women and Children. NSPCC. Retrieved from https://www.nspcc.org.uk/globalassets/documents/research-reports/domestic-violencechild-contact-post-separation-violence-report.pdf

Thornhill, C. (2006). Luhmann's Political Theory: Politics After Metaphysics? In M. King \& C. Thornhill, (Eds.), Luhmann on Law and Politics (pp. 75-100). Oxford: Hart Publishing.

Trinder, E. (2014). The support needs and impact of litigants in person: what can research tell us? Family Law 44, 664-666.

Trinder, E., Hunter, R., Hitchings, E., Miles, J., Moorhead, R., Smith, L., Sefton, M., Hinchley, V., Bader K., \& Pearce, J. (2014). Litigants in Person in Private Family Law Cases. London: Ministry of Justice. Retrieved from https://www.gov.uk/government/uploads/system/uploads/attachment data/file/380479/litigan ts-in-person-in-private-family-law-cases.pdf

Van Krieken, R. (2006). The Socio-Legal Construction of the 'Best Interests of the Child': Law's Autonomy, Sociology, and Family Law. In M. Freeman (Ed.), Law and Sociology: Current Legal Issues 2005 (pp. 437-458). Oxford: Oxford University Press.

Wall. L.J. (2006). A Report to the President of the Family Division on the Publication by The Women's Aid Federation of England and entitled 'Twenty-Nine Child Homicides: Lessons still to be learnt on domestic violence and child protection' with Particular Reference to the Five Cases in which there was Judicial Involvement (2006). Retrieved from www.judiciary.gov.uk/resources/JCO/documents/report_childhomicides.pdf 
Williams, K. (2011). Litigants in person: a literature review. London: Ministry of Justice. Retrieved from http://bit.ly/1ps6BQw

Women's Aid. (1997). Women's Aid Federation Briefing Paper on Child Contact and Domestic Violence. Bristol: Women's Aid Federation.

Ziegert, K. A. (2005). Systems Theory and Qualitative Socio-Legal Research. In R. Banakar \& M. Travers, (Eds.), Theory and Method in Socio-Legal Research (pp. 49-67). Oxford: Hart Publishing. 